\title{
Studies on the Suburban Forests in China (II) - A Case Study of Forest for Water Conservation in Shenyang ${ }^{* 1}$ -
}

\author{
Qingwei Guan*2, Liguo Li ${ }^{* 3}$, Qinglin Zhong ${ }^{* 4}$, Yuji Uozumi*5, \\ Tatsuhito Ueki ${ }^{* 5}$ and Hexin Wang ${ }^{* 5}$
}

\begin{abstract}
China, as one of the biggest developing country in the world, is facing many environmental problems accompanying with the rapid economic development and increasing population. The water supply shortage is one of the most serious problems. The total water resource is about 2,800 billion $\mathrm{m}^{3}$, and water resource per capita is $2,200 \mathrm{~m}^{3}$ in China. It only makes up a quarter of the world average level and half of the Japan. Water problems in the urban areas are more serious than in the rural areas. Now, two thirds of the cities are experiencing moderate to high water shortage. The water resources that can be used have become less and worse than before. The quantity and quality of water resources have become key factors that affect the economic development and people's life in China, especially in the urban areas in recent years. To control flood and provide water for the industry, agriculture and residents, a lot of dams and water conservation projects have been built in China in past several decades. However, the water problems have not been put to an end yet. To increase quantity and improve the quality of the water resources, plantation, as a major measure, has been done in the watersheds of China since 1980's. Up to now, there are many researches about forest for water conservation in large valleys. However, there is a little research about forest for water conservation in metropolises. The goal of this paper is to gain a better understanding of the present situation and issues of the forest for water conservation in metropolises. Shenyang, one of the biggest cities in northeastern China, was investigated. The results showed that the percentage of forest for water conservation is only $7.7 \%$, lower than the percentage of timber forest in Hunhe watershed, which provides surface water resources for the city of Shenyang, which is much lower than the percentage of forest for water conservation in Japan. Its forest age is very young. $85 \%$ of the stand area of forest for water conservation is below 40 years old. Also, its stand volume is low. In order to increase the forest area for water conservation and improve its quality, transferring the timber forest into the forest for water conservation by management of the long-term cutting was recommended. It was suggested that the approach of Closing Mountain to Regenerate Forest, which has low cost and better effect, should be popularized in the Hunhe watershed.

Keywords: China, forest for water conservation, Hunhe watershed, metropolis
\end{abstract}

${ }^{* 1}$ Portions of this paper were presented at the 113th Annual Meeting of the Japanese Forestry Society.

${ }^{* 2}$ Doctoral Program in Agricultural Science, United Graduate School of Agricultural Science, Gifu University, Laboratory located at Shinshu University, 8304 Minamiminowa, Kamiina, Nagano 399-4598, Japan

${ }^{* 3}$ Forestry Department of Liaoning Province, No.2, Taiyuan Street, Shenyang 110011, China

${ }^{* 4}$ Forestry Bureau of Fushun City, No.1, Dehui Road, Fushun, 113006, China

${ }^{* 5}$ Faculty of Agricultural Science, Shinshu University, 8304 Minamiminowa, Kamiina, Nagano 3994598, Japan

\section{INTRODUCTION}

The comprehensive assessment of the freshwater resources of the world shows that about one third of the world population lives in countries that are experiencing moderate-tohigh water stress and by the year 2025 as much as two thirds of the world's population could be living under similar level of water stress. The implications for developing countries are evident from the fact that three quarters of the population living under conditions of moderate-to high water stress amounting to $26 \%$ of the total world population is located in low to lower middle income countries (SECRETARY GENERAL OF UNitEd NATIONS, 1998). 
China, as one of the biggest developing countries in the world, is experiencing serious water stress now. According to the assessment of the water resources in China, the total water resource is about 2,800 billion $\mathrm{m}^{3}$, and water resources per capita are $2,200 \mathrm{~m}^{3}$. It only makes up a quarter of the average level of the world, half of the Japan. (QIAN and ZHANG, 2001). The quality of the surface water and underground water are very poor, because of the various degrees of pollution. The silt in the Huanghe River is the highest in the world. (MINISTRY of WATER ResOurCES OF CHINA, 2001).

Water problems in the urban areas are more serious than the rural areas in China. Two thirds of the cities are facing water supply shortage. The United Nation recognized Shanghai, the biggest city in China, as one of the most serious water supply shortage cities in the world. In Beijing, water resources per capita are only $300 \mathrm{~m}^{3}$. Water crisis has occurred several times since 1980's (WATER Resources DePARTMENT OF BeIJING, 2001). The quantity and quality of water resources have become key factors that affect economic development and people's living in China.

A lot of dams and other water conservation projects have been built to increase water resources in the past decades, such as Sanxia Dam and the Project of Transferring Southern Water to North, which are giant projects in China and will take hundreds billion RMB (Chinese Yuan). However, at present, accompanying with the rapid economic and population growth, the water resources that can be used have become less and worse than before (QIAN and ZHANG, 2001). Also, it has been recognized that water problems cannot be put to an end once for all by the dam only.

In order to increase quantity and improve quality of water resources, many ecological projects that took plantation as a major measure, have been working in large watersheds in China since 1980 's. Up till now, there are many researches related to the forest for water conservation in Yangtze and Huanghe watersheds etc. (Yu and Yu, 2001), but there is little research about water conservation forest in metropolises. This article aims to gain a better understanding of the present situation and issues of the forest for water conservation in metropolises. Shenyang, the biggest city in northeastern China, was investigated.

\section{STUDY SITES AND METHOD}

Shenyang is the capital of Liaoning province and the fifth largest city in China and it is located in northeastern China. It governs Shenhe, Heping, Tiexi, Huanggu, and Dadong 5 districts that are in the urban areas, Yuhong, Shujiatun, Dongling, and Xinchengzi 4 districts in suburban areas and Xinmin, Liaozhong, Kangping, and Faku 4 counties in rural areas. The total land area of Shenyang is $12,980 \mathrm{~km}^{2}$ and 3,495 $\mathrm{km}^{2}$ in urban areas. Most of its areas are plains. Mountains and hills are centered in Shujiatun, Dongling and Xinchengzi districts located in its southeastern portion. The total

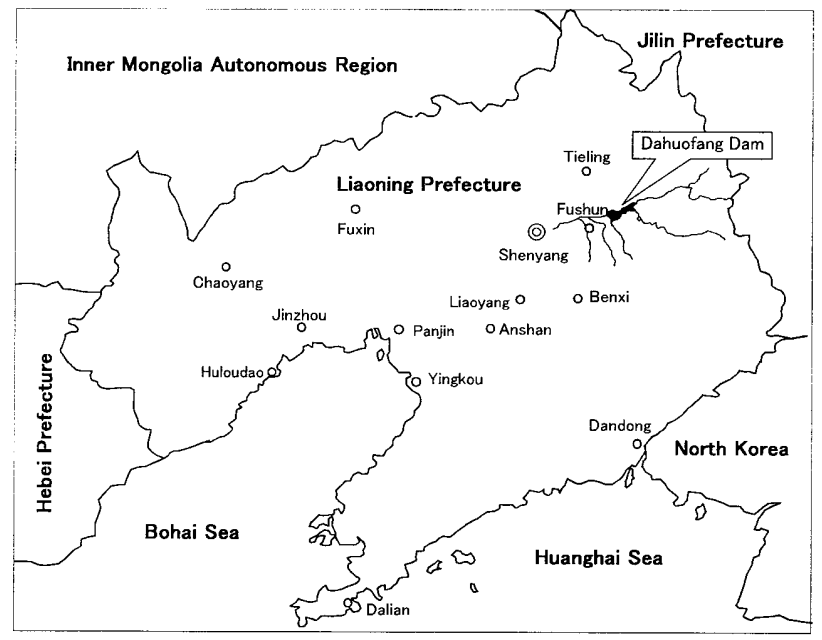

Fig. 1 The map of the investigation site

population in 1999 was 6.8 million including 4.8 million urban people. The annual average precipitation in Shenyang is $561 \mathrm{~mm}$, making it an arid or semi-arid climate zone. Liaohe River, Hunhe River and Xiushuihe River run across Shenyang. The Dahuofang dam that supplies over $50 \%$ of water resources to Shenyang is in the upper reaches of Hunhe watershed. It is $55 \mathrm{~km}$ away to the east of Shenyang, located in Fushun city of Liaoning province (Fig. 1).

According to the Construction Planning of the Forest for Water Conservation in Liaoning province, the construction content of the forest for water conservation includes 32 districts (counties) of 7 cities. However, the content of forest for water conservation for Shenyang city was not designated in the planning. Considering that the surface water resources of Shenyang mainly come from Dahuofang dam, the content of the forest for water conservation of Shenyang should include Shuncheng, Fushun, Xinbin, and Qingyuan 4 counties (district) of Fushun city that are located in the upper reaches of Hunhe watershed, and Shujiatun, Dongling, and Xinchengzi 3 districts of Shenyang city.

Based on the Forest Resources Survey data and development planning of forest for water conservation in Liaoning province, the present situation of forest for water conservation in Shenyang was analyzed. Considering the water consumption in Shenyang and economic status of the counties (districts) in the watershed, low cost and effective management of forest for water conservation were discussed.

\section{RESULTS AND DISCUSSION}

\section{A Short History of Forest for Water Conservation}

The construction of forest for water conservation in Shenyang began in 1980's followed by the construction of shelter forest in the northeastern, northwestern, and north of 
China. Because water crisis occurred in the city group where Shenyang was taken as center in 1986 , the government took more attention to the construction of forest for water conservation than before. Since 1987, 20 million RMB was invested by the government for plantation at large scale in eastern Liaoning province. In the following projects, Complex Forest Development in the Eastern Mountain of Shenyang in 1989, Comprehensive Agricultural Development in the Eastern Mountain of Liaoning Province in 1990, the Project of Shelter Forest in the Liaohe Watershed in 1994, and the Ecological Demonstration Region Establishment in Sujiatun district and Xinbin county, which are located in the Hunhe watershed in 1995, the forest for water conservation has been planted. Up to now, the forest area for water conservation has reached 55 thousand ha in Hunhe watershed (Forestry DEPARTMENT OF Liaoning Province, 1997; Forest Bureau of Shenyang, 1998).

Current Situation and Issues of the Forest for Water Conservation

According to the statistical criteria of National Forest Resources Survey, forest area includes the area of stand, economic forest and bamboo forest. The stand consists of timber forest, shelter forest, fuel forest and special use forest, does not include economic forest and bamboo forest.

In China, shelter forests refer to those that protect crops, combat desert, conserve water etc. The shelter forests in Hunhe watershed only serve the purpose of water conservation, thus they are considered as forests for water conservation.

Based on the Forest Resources Survey data of Liaoning province in 1998 , the total forest area was 714 thousand ha including 608 thousand stand area, and the forest coverage reached $52.2 \%$ in Hunhe watershed. The stand area for water conservation was 55 thousand ha, including 21 thousand ha of artificial forest and 34 thousand ha of secondary forest. All of the artificial forest was pure even-aged stand, and the stand volume amounted to $105 \mathrm{~m}^{3} / \mathrm{ha}$. It was only one third of the average volume of Japanese larch timber forest aged at 30 years old located at middle productivity class in Nagano province, Japan. The stand volume of secondary forest was $67 \mathrm{~m}^{3} /$ ha. It was close to the standard of poor forest. The stand area for water conservation was only $7.7 \%$ of all forest area in Hunhe watershed. It is much lower than the $25 \%$ of forest for water conservation in Japan. Therefore the first issue is that the ratio of forest for water conservation is very low in Hunhe watershed, and its stand volume is low also. The basic information of 7 districts (counties) in Hunhe watershed can been seen in Table 1 .

The Forest Resources Survey data also showed that the stand area reached 608 thousand ha including 519 thousand ha of timber forest. It accounted for $85.4 \%$ of the total stand area. The shelter forest area was only 55 thousand ha, and $9.1 \%$ of all stand area in Hunhe watershed. The reason that the ratio of timber forest is very high is that Hunhe watershed was assigned to the timber productivity base of Liaoning province 30 years ago. The annual output of wood amounted to 550 thousand $\mathrm{m}^{3}$, which accounts for one third of the province (Forestry Department of Liaoning Province, 2001). How to balance the proportion between the timber forest and forest for water conservation becomes another important issue (Fig. 2).

The third issue is the imbalance of the distribution of age classes. The results of Forest Resources Survey showed that the stand area with forest age below 20 and between 21 and 30 years old were $36.9 \%$ and $48.5 \%$ of all stand area respectively. It is obvious that the forest age is very young in Hunhe watershed (Fig. 3).

Based on the current situation of the forest for water conservation, its proportion is very low and the forest age is very young with low stand volume. It is not favorable for the forest to conserve water and improve water quality. In

Table. 1 The basic information in the Hunhe watershed

\begin{tabular}{|c|c|c|c|c|c|c|c|c|c|c|c|}
\hline \multirow[t]{2}{*}{$\begin{array}{l}\text { District } \\
\text { (County) }\end{array}$} & \multirow{2}{*}{$\begin{array}{c}\text { Land area } \\
\text { (ha) }\end{array}$} & \multirow{2}{*}{$\begin{array}{c}\text { Population } \\
\text { (10,000 people) }\end{array}$} & \multirow{2}{*}{$\begin{array}{l}\text { Forest area } \\
\text { (ha) }\end{array}$} & \multirow{2}{*}{$\begin{array}{c}\text { Forest ratio } \\
\text { (\%) }\end{array}$} & \multicolumn{3}{|c|}{$\begin{array}{c}\text { Stand area } \\
\text { for water conservation }\end{array}$} & \multicolumn{3}{|c|}{$\begin{array}{c}\text { Stand volume } \\
\text { for water conservation }\end{array}$} & \multirow{2}{*}{$\begin{array}{l}\text { Ratio of forest } \\
\text { for water conservation } \\
(\%)\end{array}$} \\
\hline & & & & & $\begin{array}{l}\text { Artificial } \\
\text { (ha) }\end{array}$ & $\begin{array}{c}\text { Secondary } \\
\text { (ha) }\end{array}$ & Subtotal & $\begin{array}{c}\text { Artificial } \\
\left(10,000 \mathrm{~m}^{3}\right)\end{array}$ & $\begin{array}{l}\text { Secondary } \\
\left(10,000 \mathrm{~m}^{3}\right)\end{array}$ & Subtotal & \\
\hline Total & $1,366,383$ & 246 & 713,852 & 52.2 & 21,122 & 34,148 & 55,270 & 222.6 & 229.2 & 451.8 & 7.7 \\
\hline Shenyang & 252,450 & 117 & 30,114 & 11.9 & 3,070 & 2,507 & 5,577 & 22.6 & 16.9 & 39.5 & 18.5 \\
\hline Shujiatun & 76,200 & 42 & 8,183 & 10.7 & 384 & 29 & 413 & 2.6 & 0.1 & 2.7 & 5.0 \\
\hline Dongling & 88,587 & 45 & 8,234 & 9.3 & 197 & 110 & 307 & 2.9 & 0.9 & 3.8 & 3.7 \\
\hline Xinchengzi & 87,663 & 30 & 13,697 & 15.6 & 2,489 & 2,368 & 4,857 & 17.1 & 15.9 & 33.0 & 35.5 \\
\hline Fushun & $1,113,933$ & 129 & 683,738 & 61.4 & 18,052 & 31,641 & 49,693 & 200.0 & 212.3 & 412.3 & 7.3 \\
\hline Shuncheng & 56,810 & 38 & 16,193 & 28.5 & 154 & 28 & 182 & 0.5 & 0.1 & 0.6 & 1.1 \\
\hline Funshun & 220,638 & 24 & 108,930 & 49.4 & 6,292 & 3,377 & 9,669 & 101.3 & 23.2 & 124.5 & 8.9 \\
\hline Xinbin & 443,190 & 32 & 263,174 & 59.4 & 2,909 & 17,662 & 20,571 & 23.8 & 115.5 & 139.3 & 7.8 \\
\hline Qingyuan & 393,295 & 35 & 295,441 & 75.1 & 8,697 & 10,574 & 19,271 & 74.4 & 73.5 & 147.9 & 6.5 \\
\hline
\end{tabular}

Sources: Forestry Department of Liaonig Prefecture, 1998, the statistics of forest resources of Liaoning prefecture 


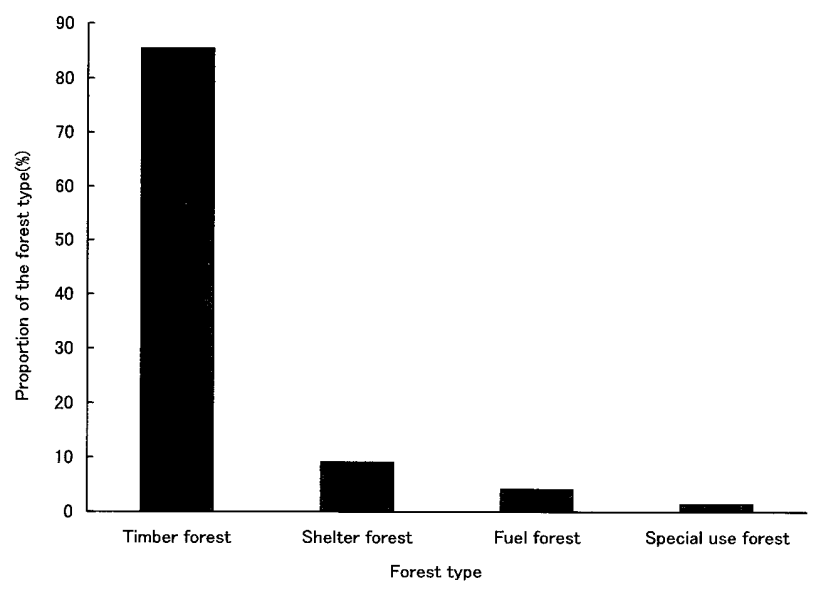

Fig. 2 The composition of forest type in the Hunhe watershed

Sources: Forestry Department of LiaOning PREFecTURE, 1998, the statistics of forest resources of Liaoning prefecture

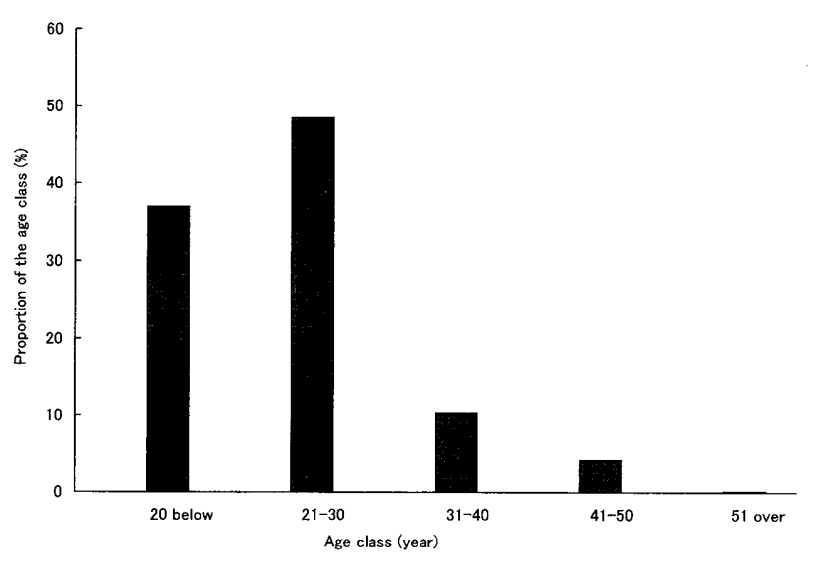

Fig. 3 The distribution of age class of forest for water conservation in the Hunhe watershed

Sources: Forestry Department of Liaoning Prefecture, 1998, the statistics of forest resources of Liaoning prefecture

Shenyang, the water consumption was 2.3 billion $\mathrm{m}^{3}$ in 2001 . It has been predicted that the water consumption will reach 3 billion $\mathrm{m}^{3}$ and 3.5 billion $\mathrm{m}^{3}$ respectively by 2010 and 2020 (Water Resources Department of Shenyang, 2001). However, the supply of underwater cannot be increased anymore because of over-exploitation in the past years. It is strongly expected to increase water supply from surface water. The forest for water conservation, which can increase the supply of surface water, becomes more important than before. How to enlarge the area of forest for water conservation and improve its quality are big challenges for the government and foresters.

\section{The Management of Forest for Water Conservation}

The forest for water conservation in Hunhe watershed decreased greatly. Its quality became worse than before because of the war and illegal cutting hundreds of years ago. The forest type was changed from Korea pine (Pinus koraiensis Sieb. Et Zucc.) broadleaf virgin forest into the poor secondary forest and barren hill (EDITORIAL BOARD OF LIAONING FOREST, 1990). Accompanying the plantation at large scale since 1950 , the forest was recovered gradually.

\section{The Management of Artificial Forest}

Japanese larch (Larix leptolepis Gord.), which was introduced from Japan hundreds of years ago, is taken as one of the major species to be planted at scale of 10 thousand ha in a year (WANG, 1992; WANG, 2001). The plantation sites where the thickness of soil is over $50 \mathrm{~cm}$ with rich humus are selected. The bush and weeds are cleared, and then the pits with size of $40 \mathrm{~cm}$ by $30 \mathrm{~cm}$ are dug before plantation. The densities of plantation vary with the purposes of management, site index and demands of the wood etc. If the purpose of management is to produce large diameter wood that Diameter at Breast Height $(\mathrm{DBH})$ is over $24 \mathrm{~cm}$, the density of plantation will be low. On the other hand, if the purpose is to produce small diameter wood that DBH is below $14 \mathrm{~cm}$, the density will be high. Generally speaking, they vary from 1,330 trees/ha to 4,050 trees/ha. The cost of plantation is about $1,800 \mathrm{RMB} / \mathrm{ha}$ in Hunhe watershed, and it will increase with the increase of the density (Tian, 1995).

The thinning will be done when the canopy become closed after 10 years old for the Japanese larch artificial forest. The thinning ratio varies from $10 \%$ to $30 \%$ with plantation density and forest age. The Table 2 showed that the thinning ratios increase with the increase of the plantation densities, and their variation with the forest ages. However, if the stand density of Japanese larch forest in Hunhe watershed is compared with larch stand in Nagano province of Japan, when the forest age is below 50 years old, the stand densities of Japanese larch forest in Hunhe watershed are much higher than that of Nagano at approximate productivity class and same age. For example, when the forest age is 30 years old,

Table. 2 The change of thinning ratios with different plantation density and stand age (Unit: \%)

\begin{tabular}{ccccc}
\hline $\begin{array}{c}\text { Plantation density } \\
\text { (trees/ha) }\end{array}$ & 10 year & 17 year & 24 year & 31 year \\
\hline 4,050 & 15 & 20 & 30 & 20 \\
3,330 & 10 & 15 & 25 & 20 \\
2,490 & 0 & 10 & 15 & 20 \\
2,000 & 0 & 0 & 15 & 15 \\
1,330 & 0 & 0 & 0 & 0 \\
\hline
\end{tabular}

Sources: Tian, Z., 1995, the silviculture of Japanese larch 


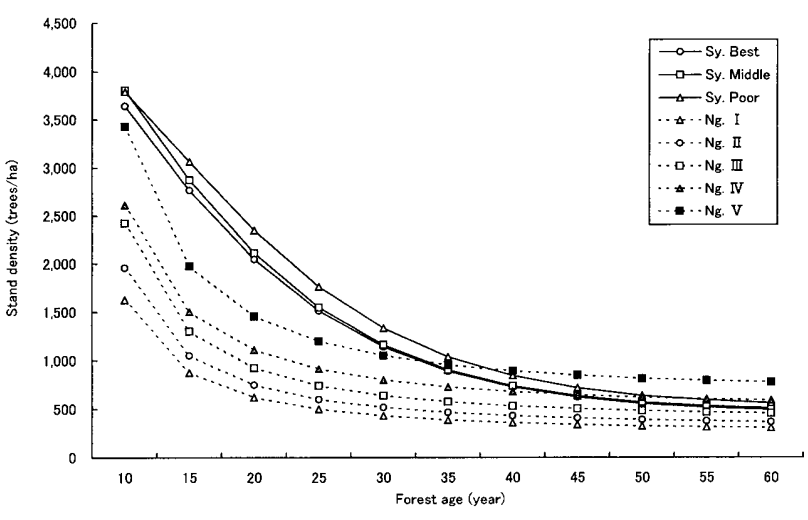

Fig. 4 The comparison of larch stand density between Shenyang and Nagano at different productivity class Sources: Tian, 1995, the silviculture of Japanese larch Forestry Department of Nagano Prefecture, 1991, the handbook of long-term management of Japanese larch artificial forest

Note: Sy.=Shenyang, Ng.=Nagano

Table. 3 The final cutting age of Japanese larch stand at different management purpose Unit: year

\begin{tabular}{|c|c|c|}
\hline \multirow{2}{*}{ Management purpose } & Poor productivity class & Better productuvity class \\
\hline & Site index at 18 below & Site index at 20 over \\
\hline $\begin{array}{l}\text { Small diameter wood } \\
\quad(\mathrm{DBH}<14 \mathrm{~cm})\end{array}$ & $17-20$ & $15-17$ \\
\hline $\begin{array}{l}\text { Middle diameter wood } \\
\text { (DBH: } 16-20 \mathrm{~cm} \text { ) }\end{array}$ & $20-13$ & $18-20$ \\
\hline $\begin{array}{l}\text { Large diameter wood } \\
\quad(\mathrm{DBH}>24 \mathrm{~cm})\end{array}$ & $40-45$ & $38-40$ \\
\hline
\end{tabular}

Sources: Tian, Z., 1995, the silviculture of Japanese larch

the stand densities vary from 1,143 trees/ha to 1,335 trees/ha at different productivity class in Hunhe watershed. But in Nagano province, they vary from 430 trees/ha to 1,051 trees/ha. When the forest age is over 50 years old, the differences of stand density between Hunhe watershed and Nagano province are diminishing (FORESTRY DEPARTMENT OF Nagano Province, 1991; Tian, 1995). The change of stand density with forest ages can be seen clearly in Fig. 4.

The final cutting age of larch stand varies with the purpose of plantation, site index and others. In terms of low site index, if the purpose of plantation is to produce small diameter wood such as pulp and rafter, the final cutting age is around 17-20 years old. If the purpose is to produce large diameter wood such as beam and $\log$, the final cutting age is around 40-45 years old. In terms of high site index, the final cutting ages of small diameter and large diameter wood are around 15-17 and 38-40 years old respectively. No matter what the purpose of the management and how site index they are in Hunhe watershed, all of the final cutting ages are below 45 years old. It is obvious that the management of Japanese larch artificial forest is characterized with a short-term cutting (Table. 3).

Based on the above investigation, the ratio of forest for conservation is very low compared with that of timber forest. The forest quality is poor. The stand density is very high with the character of short-term cutting in Hunhe watershed. It has been pointed out that it was necessary to transfer timber forest into forest for water conservation (FORESTRY DEPARTMENT OF LiAONing Province, 1996). However, how to realize the transformation has not been solved yet.

In Japan, there are many researches about the management of forest for water conservation (WATANABE, 1982; TSUKAMOTO and ОTA, 1984; TAKESHITA, 1990; ОTA, 1991; Hatrori et al., 2001). These researches showed that the best forest types for water conservation are the large diameter forest, mixed forest, broadleaf forest and multi-storied forest. The forest for water conservation has been changing from pure even-aged artificial forest to large diameter forest, mixed forest and multi-storied forest through the long-term management etc., and a lot of model forests for water conservation have been formed in Kanagawa province and Tama watershed (Forestry DEPARTMEnT OF KANAGawA Province, 1994; Waterworks Bureau of Tokyo City, 2001).

In order to search for the possibility of management of long-term cutting in Hunhe watershed, 3 plots were investigated. Plot A was located in Qingyuan county, its forest age was 62 years old, stand density was 394 trees/ha. Plot B and $\mathrm{C}$ were located in Xinbin county, their forest ages were 60 and 86 years old respectively, the stand densities were 455 and 536 trees/ha respectively. The dominant species of 3 plots was Japanese larch. The results showed that the average stand height of 3 plots was over $28 \mathrm{~m}$, and the average $\mathrm{DBH}$ was over $30 \mathrm{~cm}$. The average stand stock amounted to $540 \mathrm{~m}^{3} / \mathrm{ha}$, which was 5 times as much as the average stand volume of $105 \mathrm{~m}^{3} /$ ha in Hunhe watershed. The average volume of singletree reached over $1.2 \mathrm{~m}^{3}$, and the stock of the trees that DBH was over $30 \mathrm{~cm}$ was over $90 \%$ of all stock. (WANG, 2002). The details of the investigation can be seen in Fig. 5. The results also showed that the broadleaf trees that invaded into plots amounted to 1,200 trees/ha, and the major species were Manchurian linden (Tilia mandshurica Rupr. Et Maxim.), Chestnut (Quercus mongolica Fisch.), and Ussurian pear (Pyrus ussuriensis Maxim.) etc.

Therefore, it seems possible to produce large diameter wood by the management of long-term cutting, which implicates that it is possible to transfer timber forest into the forest for water conservation by the management of long-term cutting in Hunhe watershed. However, the issues like what thinning ratio is the best at different age class and when thinning is to be done for the management of large diameter wood still need more researches in Hunhe watershed. 


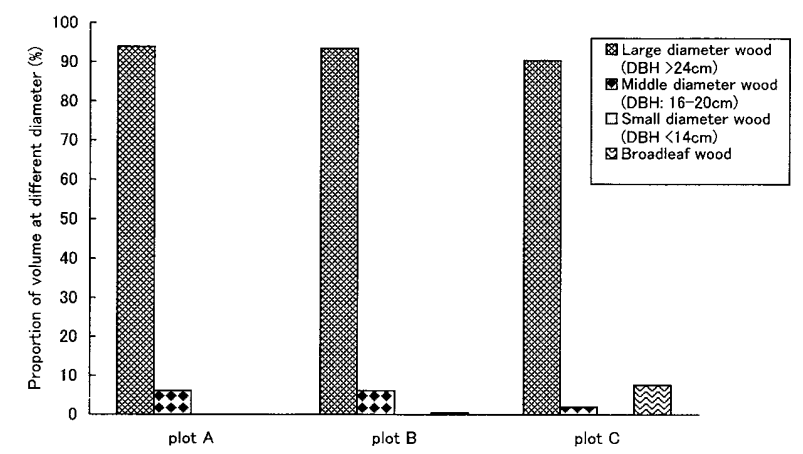

Fig. 5 The composition of volume at different diameter in the old age larch stand

Source: Wang, H., 2002, the possibility of management of long-term cutting of Japanese larch in China, Transactions of the Japanese Forestry Society

\section{The Closing Mountain to Regenerate Forest}

Because the economic statuses of the districts (counties) are at low level in Hunhe watershed, the study on how to increase forest resources with low cost and better effect has become necessary. The Closing Mountain to Regenerate Forest (CMRF) is one approach to increases forest resources in China. The natural regeneration is mainly utilized to recover forest during the process of closing mountain. It has two implications. First, any activity that is unfavorable for the regeneration of forest is forbidden during closing the mountain, such as putting out to pasture and gathering firewood etc. Second, appropriate human management will be carried out according to the growth of the young tree such as plantation, pruning and selective cutting etc. (XU and ZHENG, 1994). The area of the CMRF varies from several ha to hundreds of ha, depended on the actual situation of the stand.

According to the Forest Management Codes of Liaoning province (Technological Standard DePartment of Liaoning PROVINCE, 1993), the following objects could use the CMRF approach to recover forest in Hunhe watershed.

(1). Japanese larch below 10 years old, Korea pine below 13 years old and Black locust (Robinia Pseudoacacia L.) below 3 years old.

(2). The bush, sparse woods and cut-over area where some mother trees exist and natural regeneration can be realized. The poor secondary forest where a few good trees still exist.

(3). The poor secondary forest and young stand that located in the forest parks, natural conservation zones, around the dams and rivers or in a deep and precipitous mountains.

After the poor secondary forest and young stand are assigned as the zone of CMRF, some measures should be taken into effect, such as some people will be designated to keep watch over the region to prevent the man-made interference, such as putting out to pasture etc. Duration of
CMRF is about 10 years generally. After some young trees are regenerated by naturally seeding, a series of steps will be taken to promote the growth of the young trees. In Hunhe watershed, the following techniques are often utilized.

(1). Planting coniferous trees under the canopy after selective cutting.

This technique is suitable for the poor secondary forest. First of all, the species and quantities of young trees should be investigated. Then weeds, bush and others should be got rid of. Also, other types of trees should be cleaned up by selectively cutting. Only the good middle and small diameter designated trees should be kept. Additionally, the Korea pine, Manchurian fir (Abies holophylla Maxim.), and Yeddo spruce (Picae jezoensis Carr.), which are tolerant trees, should be planted to promote the growth of mixed forest of coniferous and broadleaf trees.

(2). Planting coniferous trees by row to form mixed forest.

This is for the sites where enough mother trees and young trees both present, and evenly distributed. The amount of the young trees regenerated by natural seeding should be controlled. Any weeds and bush that affect the growth of young trees should be got rid of. Based on the row spacing of $3-5 \mathrm{~m}$, the tolerant trees such as Korea pine and Manchurian fir should be planted. In order to form mixed forest earlier, eliminating the weeds and adjusting the proportion of the coniferous and broadleaf trees are very necessary after 2-3 years of plantation.

(3). Planting the coniferous trees by group to form mixed forest.

This is suitable for the location where quantities of young trees regenerated by naturally seeding are not a lot, and unevenly distributed. Because of the uneven distribution of the young trees, the tolerant trees such as Korea pine and Manchurian fir are planted by 3-7 coniferous tree group where there are no young trees regenerated. The area of each group is about $5 \mathrm{~m}^{2}$. After plantation, in order to balance the proportion between coniferous and broadleaf trees, it is necessary to clean up poor trees and non-designated trees.

Considered as the effect of CMRF, if the mountain could be closed indeed, the forest should be recovered by natural regeneration and the stand structure would be very similar to natural forest. There are many successful cases of CMRF in China. The Laoshigou forestry farm, which locates in Hunhe watershed, is a typical case of CMRF.

The total area of the forestry farm is 983 ha which includes 410 ha of the stand governed by the Committee of Communist Party of Shenyang. In order to keep its important documents, the forestry farm has been closed since 1960's. Now, the forest has grown up to the stable mixed forest. The biological species are abundant. The majority are middle-aged and matured forests. According to the survey of Forestry Bureau of Shenyang, the area of the stand below 20 years old is 29 ha, which consists of $7.1 \%$ of all stand area. The 


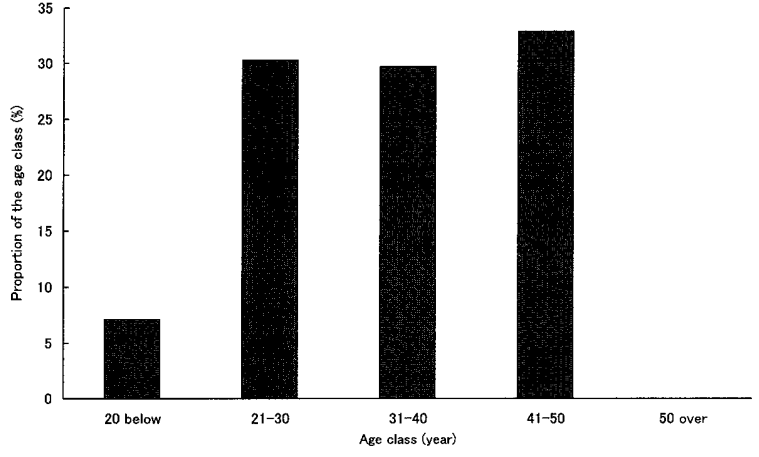

Fig. 6 The distribution of age class in Laoshiguo forestry farm

Sources: Forestry department of Liaoning prefecture, 1998, the statistics of forest resources of Liaoning prefecture

Table. 4 The comparison of cost between plantation and CMRF

\begin{tabular}{|c|c|c|c|}
\hline \multirow{2}{*}{ Area } & CMRF & Plantation & CMRF/Plantation \\
\hline & (RMB/ha) & (RMB/ha) & $(\%)$ \\
\hline $\begin{array}{l}\text { Chaoyang city, } \\
\text { Liaoning prefecture }\end{array}$ & 196 & 978 & 20.0 \\
\hline $\begin{array}{l}\text { Panshi county, } \\
\text { Jilin prefecture }\end{array}$ & 226 & 1,419 & 15.9 \\
\hline $\begin{array}{l}\text { Qingyuan county, } \\
\text { Liaoning prefecture }\end{array}$ & 161 & 1,483 & 10.9 \\
\hline
\end{tabular}

Sources: Zhao, R., 1995, silviculture in the semi-arid area

Table. 5 The cost of CMRF in the watershed of Shenyang Unit: RMB/ha

\begin{tabular}{lc}
\hline \multicolumn{1}{c}{ Category of expense } & Cost \\
\hline Total & 228 \\
Keeping watch over the forest & 15 \\
Training for forester & 5 \\
Purchasing the fire protection tools & 76 \\
Purchasing the communication tools & 8 \\
Conducting propagangda among citizen & 5 \\
Controll of diseases and pest & 14 \\
Monitoring of the forest & 5 \\
Thinning and plantation & 60 \\
Construction of the forest road and bridge & 30 \\
Others & 10 \\
\hline
\end{tabular}

Sources: Forestry Bureau of Fusun, 2001, data service

percentage is much lower than $36.9 \%$ in the watershed at same age class. The area of stand between 31 and 40 years old is 124 ha, which accounts for $30.3 \%$ of all stand area, lower than $48.5 \%$ in the watershed at same age class. However, the stand area aged over 41 years old is 256 ha, about $62.6 \%$ of all stand area. It is much higher than $14.6 \%$ in Hunhe watershed at same age class. The different ratio of each age class of Laoshigou forestry farm can be seen in Fig. 6 .

Because less or no seedlings were planted during CMRF in comparison with plantation, there is less or no expense on the management of seedling. The cost of CMRF is much less than that of plantation, but it varies in different regions. Many researches showed that the cost of CMRF was about one fourth of the plantation in general (YU and Yu, 2001; ZHAO, 1995; XU and ZHENG, 1994). It was showed in Table 4. In Hunhe watershed, the cost of plantation is about 1800 $\mathrm{RMB} /$ ha in recent years, and the cost of CMRF is about 228 $\mathrm{RMB} / \mathrm{ha}$, which accounts for $12.7 \%$ of the plantation. The details of the cost of CMRF were showed in the Table 5 .

The above study showed that the forest could be recovered effectively by CMRF, which cost is much lower than plantation. This indicates that CMRF should be applied at large scale in the future.

\section{CONCLUSION}

Shenyang, as the biggest city in northeastern China, is involved in serious water stress. There are 2 approaches to solve the problem. One is through the increase of water supply, and another is through saving water strategy. However, followed by the rapid economic development and improvement of the people's living standard, the demand for water consumption will be increased, digging more underwater to meet the needs of water consumption is not possible in Shenyang because of over-exploitation in the past. To increase the supply of surface water is imperative now. Therefore, the forest for water conservation becomes more important than before.

Many researches showed that the best forest types for water conservation are the large diameter forest introduced by long-term management and natural forest etc. Unfortunately, in Hunhe watershed, because of the war and illegal cutting, the virgin forests do not exist anymore, and the young artificial forest with high density aimed at producing timber primarily and the secondary forest with poor quality are the major forest types. The proportion of the forest for water conservation is very low. It does not match the growing needs of increasing water supply and improving water quality. It is necessary to expand forest area and improve its quality for water conservation in Hunhe watershed.

To transfer the timber forest into the forest for water conservation by the management of long-term cutting is possible in Hunhe watershed. Not only can the forest area for water conservation be increased, but also the conflict between economic and environmental benefit could be minimized or even solved.

CMRF is one of the effective approach to increase forest area and improve the forest quality in Hunhe watershed. This approach is proved to be less costly and suitable for Shenyang to recover forest. It should be popularized furthermore in the 
future. However, the mountain must be closed reliably during the closing mountain. It is here, challenges remain for the government, foresters and local people, such as how to deal with the issues that local people used to gather firewood and put out to pasture in the region of CMRF, after mountain is closed. The available policies and techniques should be drawn up in the future.

\section{ACKNOWLEDGEMENT}

The authors gratefully thank professor Robert W. MILLER of the University of Wisconsin who provided very helpful comments on the manuscript.

\section{LITERATURE CITED}

Association of Forestry Improvement of JAPAN, (1999): Forest and water. Association of Forestry Improvement of Japan, Tokyo, $53 \mathrm{pp}$ (in Japanese) ${ }^{*}$

EdtToRial BoARd of Liaoning Forest, (1990): The forest of Liaoning province. Liaoning Scientific and Technological Press, Shenyang, 358pp (in Chinese) ${ }^{*}$

Forest Bureau of Shenyang, (1998): The statistics of forestry of Shenyang in 1997. Data service (in Chinese) ${ }^{*}$

Forestry Department of Kanagawa Province, (1994): The handbook of management of forest for conservation in Kanagawa province, 55pp (in Japanese) ${ }^{*}$

Forestry Department of Liaoning Province, (1996): The general development planning of forest for water conservation of Liaoning province (1993-2010). Data service (in Chinese) ${ }^{*}$

Forestry Department of Liaoning Province, (1997): The statistics of forestry of Liaoning province in 1996. Data service (in Chinese) ${ }^{*}$

Forestry Department of Liaoning Province, (2001): The statistics of forest resources of Liaoning province. Data service (in Chinese) ${ }^{*}$

Forestry Department of Nagano Province, (1991): The handbook of long-term management of Japanese larch artificial forest. Data service (in Japanese) ${ }^{*}$

Hattori, S., Shimizu, K., Araki, M., Kosugi, K. and Takeuchi, I., (2001a): The present situation of the study on forest's headwater conservation function and how to maintain and improve it's function (I) the survey report on the maintainable guideline of forest at the upper river region in water famine. Water Science $\mathbf{4 5}$ (3): 1-40 (in Japanese) ${ }^{*}$

Hattori, S., Shimizu, K., Araki, M., Kosugi, K. and Takeuchi, I., (2001b): The present situation of the study on forest's headwater conservation function and how to maintain and improve it's function (II) the survey report on the maintainable guideline of forest at the upper river region in water famine. Water Science $\mathbf{4 5}$ (4): 48-74 (in Japanese)*
Ministry of Water Resources of China, (2001): The water resources bulletin in China. Data service (in Chinese) ${ }^{*}$

OTA, T., (1991): A private plan on the right way about headwater conservation functions of forest and afforestation project. Water Science 34(6): 1-33 (in Japanese) *

QIAN, Z. and Zhang, G., (2001): The study on sustainable development of water resources in China. Chinese Water Resources Press, Beijing, 284pp (in Chinese) ${ }^{*}$

Secretary General of United Nations, (1998): Strategic approaches to freshwater management. Commission on sustainable development sixth session. Data service.

TAKESHITA, K., (1990): Headwater conservation and forest. Water Science 34(2): 1-19(in Japanese) *

Technological Standard Department of Liaoning, (1993): Forest management code of Liaoning province, Data service (in Chinese) ${ }^{*}$

TIAN, Z., (1995): The silviculture of Japanese larch. Beijing Agricultural University Press, Beijing, 192pp (in Chinese) ${ }^{*}$

Tsukamoto, Y., and OTA, T., (1984): Introduction to forest works for water management. Water Science 28(3): 28-61 (in Japanese) *

WANG, H., (2001): The present situation and problems about larch forest in China. J. Jpn. For. Plann. 35: 93-98 (in Japanese) ${ }^{*}$

WANG, H., (2002): The approach about management of long-term cutting of Japanese larch in China. Transactions of the Japanese Forestry Society 113:267-268 (in Japanese) ${ }^{*}$

WANG, Z. and ZHANG, S., (1992): The larch forest in China. Chinese Forestry Press, Beijing, 259pp (in Chinese) ${ }^{*}$

Watanabe, S., (1982): The forest management and headwater conservation. Forest Technology 485: 7-13(in Japanese)*

Water Resources Department of Bejing, (2001): The water resources bulletin in Beijing. Data service (in Chinese)*

Water Resources Department of Shenyang, (2000): The development strategy of water resources in Shenyang. Data services (in Chinese) ${ }^{*}$

Water Resources Department of Shenyang, (2001): Water resources bulletin of Shenyang in 2001. Data services (in Chinese) ${ }^{*}$

$\mathrm{X}_{\mathrm{U}}, \mathrm{H}$. and ZHENG, J., (1994): The approach of closing mountain to regenerate forest. Chinese Forestry Press, Beijing, 388pp (in Chinese) ${ }^{*}$

YU, X. and YU, Z., (2001): Forest for water resources protection silviculture management evaluation. Chinese Forestry Press, Beijing, 387pp(in Chinese)*

Zнао, R., (1995): Silviclture in the semi-arid area. Beijing Agricultural University Press, Beijing, 282pp (in Chinese) ${ }^{*}$

* The titles are tentative translations from original Chinese and Japanese by the authors of this paper

(Received 4 June 2002)

(Accepted 1 March 2003) 